\title{
Peramalan Jumlah Siswa Baru Madrasah Aliyah (MA) Manhalul Ma'arif Darek-Lombok Tengah
}

\author{
Lisa Harsyiah $^{a}$, Nurul Fitriyani ${ }^{b}$, Salwa ${ }^{c}$ \\ ${ }^{a}$ Program Studi Matematika, FMIPA, Universitas Mataram, Jl. Majapahit No. 62, Mataram , Indonesia, 83125. \\ Email: lisa_harsyiah@unram.ac.id

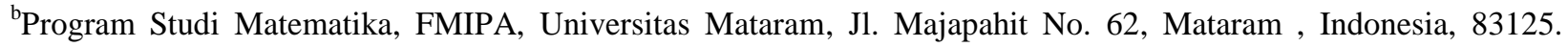 \\ Email: nurul.fitriyani@unram.ac.id \\ ${ }^{c}$ Program Studi Matematika, FMIPA, Universitas Mataram, Jl. Majapahit No. 62, Mataram , Indonesia, 83125. \\ Email: salwa@unram.ac.id
}

\section{A B S T R A C T}

This study aimed to forecast the new student number at Madrasah Aliyah (MA) Manhalul Ma'arif Darek. The data used in this study was the annual time series data of new students who enrolled in the school, from the 1998/1999 academic year to 2016/2017. Based on the data obtained, it shows that the number of new students who enroll in Madrasah Aliyah (MA) Manhalul Ma'arif Darek tends to fluctuate. This fluctuating pattern is a problem faced by Madrasah Aliyah (MA) Manhalul Ma'arif Darek in determining strategic and policy steps related to planning the provision of school facilities / infrastructure. Therefore we need a forecasting method in accordance with the data pattern. The forecasting method used is the Fuzzy Time Series Cheng method. This method uses fuzzy principles as the basis of the forecasting process. The forecasting process results obtained the Mean Square Error (MSE) value of 101.5009 and the Mean Absolute Percentage Error (MAPE) value of 18.49\%. The results showed that the Fuzzy Time Series Cheng method performed well in predicting the number of new students at Madrasah Aliyah (MA) Manhalul Ma'arif Darek.

Keywords: Forecasting, Fuzzy Time Series Cheng, Mean Absolute Percentage Error (MAPE), Mean Square Error (MSE), Number of new students, Time Series.

\section{A B S T R A K}

Penelitian ini bertujuan untuk memperoleh hasil peramalan jumlah siswa baru pada Madrasah Aliyah (MA) Manhalul Ma'arif Darek. Data yang digunakan dalam penelitian ini adalah data time series tahunan dari jumlah siswa baru yang mendaftar mulai tahun ajaran 1998/1999 sampai tahun 2016/2017. Berdasarkan data yang diperoleh menunjukkan bahwa jumlah siswa baru yang mendaftar di Madrasah Aliyah (MA) Manhalul Ma'arif Darek cenderung fluktuatif. Pola yang fluktuatif ini menjadi masalah yang dihadapi Madrasah Aliyah (MA) Manhalul Ma'arif Darek dalam menentukan langkah-langkah strategis dan kebijakan terkait perencanaan penyediaan

* Corresponding author.

Alamat e-mail: lisa_harsyiah@unram.ac.id 
fasilitas/infrastruktur sekolah. Oleh karena itu diperlukan metode peramalan yang sesuai dengan pola data tersebut. Metode peramalan yang digunakan adalah metode Fuzzy Time Series Cheng. Metode ini menggunakan prinsipprinsip fuzzy sebagai dasar dari proses peramalannya. Dari hasil proses peramalan menggunakan metode Fuzzy Time series Cheng diperoleh hasil peramalan selama dengan Mean Square Error (MSE) sebesar 101.5009 dan nilai Mean Absolute Percentage Error (MAPE) adalah sebesar 18.49\%. Berdasarkan hasil yang diperoleh menunjukkan bahwa metode Fuzzy Time Series Cheng performa yang bagus dalam melakukan peramalan jumlah siswa baru di Madrasah Aliyah (MA) Manhalul Ma'arif Darek.

Keywords: Analisis Runtun Waktu, Fuzzy Time Series Cheng, Jumlah Siswa Baru, Nilai Rata-rata Kesalahan Kuadrat (MSE), Nilai Rata-rata Kesalahan Persentase Absolut (MAPE), Peramalan.

\section{Pendahuluan}

Madrasah Aliyah (MA) Manhalul Ma'arif Darek adalah salah satu sekolah swasta di bawah yayasan Pondok Pesantren Manhalul Ma'arif setingkat SMA yang ada di Lombok Tengah. Sekolah ini didirikan pada tahun 1987 dan surat izin dikeluarkan pada tanggal 16 Agustus 1990 dengan status akreditasi A. Berdasarkan data yang diperoleh dari pihak sekolah bahwa tercatat sejak sekolah ini berdiri jumlah siswa baru yang mendaftar mengalami pola yang naik turun. Pola yang fluktuatif ini menjadi masalah yang dihadapi Madrasah Aliyah (MA) Manhalul Ma'arif Darek dalam menentukan langkah-langkah strategis dan kebijakan terkait perencanaan penyediaan fasilitas/infrastruktur sekolah. Oleh karena itu perlu dilakukan peramalan untuk memprediksi berapa siswa baru yang mendaftar di Madrasah Aliyah (MA) Manhalul Ma'arif Darek. Sehingga pihak sekolah bisa mendapatkan gambaran berapa orang yang akan mendaftar di sekolah ini pada tahun ajaran berikutnya.

Teknik peramalan yang digunakan dalam penelitian ini adalah metode peramalan kuantitatif karena metode ini menggunakan informasi berupa angka (kuantitas). Metode peramalan kuantitatif dapat dibagi menjadi dua yaitu model regresi dan model time series (Aswi \& Sukarna, 2006). Peramalan sendiri merupakan suatu teknik memperkirakan suatu nilai pada masa yang akan datang dengan memperhatikan data pada masa lalu maupun data saat ini (Aswi \& Sukarna, 2006). Untuk mengukur keakuratan hasil dari peramalan digunakan lima tipe pengukuran untuk menghitung seberapa besar hasil peramalan melenceng dari data yang sebenarnya (Makridakis, Wheelwright, \& Mcgee, 1999) yaitu Mean Error (ME), Mean Absolute Error (MAE), Mean Square Error (MSE), Mean Percentage Error (MPE), dan Mean Absolute Percentage Error (MAPE).
Adapun metode peramalan yang dapat meminimalkan nilai error salah satunya adalah metode peramalan Fuzzy Time Series. Metode ini mengadaptasi prinsip-prinsip fuzzy dalam pengerjaannya (Rahmawati, Cynthia, \& Susilowati, 2019). Penggunaan logika fuzzy mempunyai kelebihan yaitu konsepnya yang mudah dipahami dan sangat fleksibel serta memiliki toleransi terhadap data yang kurang tepat. Oleh karena pada penelitian ini digunakan metode peramalan Fuzzy Time Series Cheng yaitu yang merupakan pengembangan dari metode Fuzzy Time Series.Adapun kelebihan dari Fuzzy Time Series Cheng adalah metode peramalan adaptif karena merupakan perbaikan dari metode Fuzzy Time Series Chen sehingga memiliki ukuran kesalahan peramalan yang lebih kecil (Tauryawati dan Irawan, 2014). Pada penelitian ini digunakan data yang menunjukkan gerakan yang tidak tertentu atau tidak menunjukkan pola tertentu sehingga proses peramalan menggunakan metode Fuzzy Time Series Cheng yang tidak membutuhkan asumsi pola data tertentu.

\section{Landasan Teori \\ 2.1.Peramalan (Forecasting)}

Peramalan adalah suatu cara memprediksi sesuatu yang akan terjadi di masa depan menggunakan informasi yang terjadi sekarang ataupun pada masa lampau. Tujuan peramalan adalah untuk pengambilan keputusan berdasarkan data atau informasi dari masa lampau sehingga kesalahan dapat diminimalisir. Oleh karena itu peramalan memiliki sifat ketidakpastian atau kemungkinan yang memiliki kesalahan. Semakin kecil nilai kesalahan (error) dari peramalan maka keakuratan peramalan semakin baik sehingga bagus dalam pengambilan keputuan. Terdapat lima tipe pengukuran yang digunakan untuk menghitung error peramalan (Makridakis, Wheelwright, \& Mcgee, 1995) yaitu: 
a. Nilai Rata-rata Kesalahan (Mean Error)

Persamaan untuk menentukan Mean Error (ME) adalah:

$$
\begin{aligned}
& M E=\frac{\sum_{i=1}^{n} e_{i}}{n} \\
& e_{i}=X_{i}-F_{i}
\end{aligned}
$$

dimana:

$M E$ : Nilai rata-rata kesalahan (Mean Error)

$n$ : Jumlah periode waktu data

$e_{i}$ : Error pada periode waktu $i$

$X_{i}$ : Data pada periode waktu $i$

$F_{i}$ : Ramalan untuk periode waktu $i$

b. Nilai Rata-rata Kesalahan Absolut (Mean Absolute Error)

Mean Absolute Error (MAE) merupakan hasil nilai absolut dari selisih antara nilai output model dengan data sebenarnya. Persamaannya adalah:

$$
M A E=\frac{\sum_{i=1}^{n}\left|e_{i}\right|}{n}
$$

dimana:

$M A E$ : nilai rata-rata kesalahan absolut (Mean Absolute Error)

c. Nilai Rata-rata Kesalahan Kuadrat (Mean Square Error)

Mean Square Error (MSE) dihitung dengan menjumlahkan kuadrat semua error peramalan pada setiap periode dan membaginya dengan jumlah periode peramalan. Persamaannya adalah sebagai berikut:

$$
M S E=\frac{\sum_{i=1}^{n} e_{i}^{2}}{n}
$$

dimana:

$M S E$ : Nilai rata-rata kesalahan kuadrat (Mean Square Error)

d. Nilai Rata-rata Kesalahan Persentase (Mean Percentage Error)

Persamaan untuk menentukan nilai Mean Percentage Error (MPE) adalah:

$$
\begin{aligned}
& M P E=\frac{\sum_{i=1}^{n} P E_{i}}{n} \\
& P E_{i}=\frac{X_{i}-F_{i}}{X_{i}}
\end{aligned}
$$

dimana:

$P E_{i} \quad$ : Error persentase pada periode $i$

$M P E$ :Nilai rata-rata kesalahan persentase (Mean Percentage Error) e. Nilai Rata-rata Kesalahan Persentase Absolut (Mean Absolute Percentage Error) Mean Absolute Percentage Error (MAPE) menyatakan persentase error hasil peramalan terhadap permintaan aktual selama perode tertentu. Informasi yang diberikan adalah persentase error yang terlalu tinggi atau terlalu rendah. Persamaannya adalah:

$$
M A P E=\frac{\sum_{i=1}^{n}\left|P E_{i}\right|}{n}
$$

Ketepatan peramalan $100 \%-M A P E$

\subsection{Analisis Runtun Waktu (Time Series)}

Time Series diperkenalkan pada tahun 1970 oleh George E.P. Box dan Gwilym M. Jenkins melalui bukunya yang berjudul Time Series Analysis: Forecasting and Control. Sejak saat itu time series mulai banyak dikembangkan (Aswi \& Sukarna, 2006). Time Series merupakan serangkaian data pengamatan yang terjadi berdasarkan indeks waktu secara berurutan dengan interval waktu tetap. Time Series adalah salah satu prosedur statistika yang diterapkan untuk meramalkan struktur probabilistik keadaan yang akan terjadi di masa yang akan datang dalam rangka pengambilan keputusan.

\subsection{Fuzzy Time Series}

Fuzzy Time Series (FTS) diperkenalkan oleh Song dan Chissom pada tahun 1993. Fuzzy time series adalah metode peramalan data yang mengadaptasi prinsip-prinsip fuzzy sebagai dasarnya Sistem peramalan dengan metode ini bekerja dengan menangkap pola dari data historis kemudian digunakan untuk memproyeksikan data yang akan datang. Proses dari suatu sistemnya juga tidak rumit, sehingga mudah digunakan dan dikembangkan sebagaimana yang ada pada algoritma genetika dan jaringan syaraf. Pada fuzzy time series memiliki istilah-istilah yang dipelajari yaitu fuzzy logic relations (FLR) dan fuzzy logic relations group (FLRG).

\subsection{Metode Fuzzy Time Series Cheng}

Metode Fuzzy Time Series Cheng merupakan perbaikan dari algoritma Chen yang memiliki kekurangan dalam hal tidak mempertimbangkan adanya pengulangan dan tidak adanya pembobotan (weighted) yang makin kecil pada pengamatan yang lama. Menurut Sumartini, Hayati, \& Wahyuningsih (2017) langkah-langkah peramalan 
menggunakan metode fuzzy time series Cheng adalah sebagai berikut:

1. Menentukan himpunan semesta $(U)$ data aktual, yaitu:

$$
U=\left[d_{\min } ; d_{\max }\right]
$$

dimana $d_{\min }$ merupakan data terkecil dan $d_{\text {max }}$ adalah data terbesar dari pengamatan.

2. Penentuan lebar interval dimana menggunakan langkah-langkan dalam distribusi frekuensi dengan tahapan sebagai berikut:

Menghitung rentang (range) dari data yang diamati menggunakan rumus:

$$
R=d_{\max }-d_{\min }
$$

Menentukan banyaknya kelas menggunakan aturan Sturges yaitu:

$$
K=1+3,32 \log (n)
$$

Menentukan panjang kelas (interval) menggunakan rumus:

$$
l=\frac{\text { range }(R)}{\text { banyaknya kelas }(K)}
$$

Menentukan nilai tengah menggunakan rumus: $m_{i}=\frac{\text { (batas bawah }+ \text { batas atas) }}{2}$

3. Himpunan fuzzy dibentuk dengan melihat jumlah frekuensi yang berbeda dan lebih besar dari nol (frekuensi yang sama dihitung sekali).

4. Mendefinisikan himpunan fuzzy $A i$ dan melakukan fuzzifikasi pada data aktual yang diamati. Jika

$$
U=\left[u_{1}, u_{2}, \ldots, u_{k}\right]
$$

merupakan himpunan semesta, maka himpunan fuzzy $A_{i}$ dari $U$ dengan derajat keanggotaannya dinyatakan sebagai berikut:

$A_{i}=\left\{\mu_{A_{i}}\left(u_{1}\right) / u_{1}+\cdots+\mu_{A_{i}}\left(u_{p}\right) / u_{p}\right\}$

dengan $\mu_{A_{i}}\left(u_{j}\right)$ merupakan derajat keanggotaan dari $u_{j}$ ke $A_{i}$ dimana $\mu_{A_{i}}\left(u_{j}\right) \epsilon[0,1]$ dan $1 \leq j \leq p$ dimana $p$ merupakan banyak kelas. Nilai derajat keanggotaan dari $\mu_{A_{i}}\left(u_{j}\right)$ didefinisikan sebagai berikut:

$\mu_{A_{i}}\left(u_{j}\right)=\left\{\begin{array}{cr}1, & \text { jika } i=j \\ 0.5, & \text { jika } i=j-1 \text { atau } j+1 \\ 0, & \text { yang lainnya }\end{array}\right.$
5. Membuat tabel Fuzzy Logical Relationship (FLR) yang dinotasikan dengan $A_{i} \rightarrow A_{j}$, dengan $A_{i}$ adalah current state dan $A_{j}$ disebut next state.

6. Menentukan bobot relasi FLR menjadi Fuzzy Logical Relationship Group (FLRG) dengan memasukkan semua hubungan (all relationship) dan memberikan bobot berdasarkan pada urutan dan perulangan yang sama. Kemudian bobot yang diperoleh pada relasi FLR disubstitusikan ke dalam matriks pembobot (W) dengan bentuk sebagai berikut:

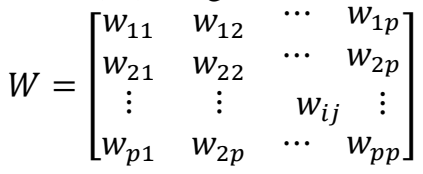

dimana $W$ adalah pembobot dari $W_{i j}$ yang merupakan bobot matriks pada bariks ke- $i$ dan kolom ke- $j$ dengan $i=1,2, \ldots p$ dan $j=$ $1,2, \ldots p$.

7. Mentransfer bobot FLRG ke dalam bentuk matriks pembobot terstandarisasi $\left(\mathrm{W}^{*}\right)$ yaitu sebagai berikut:

$$
W^{*}=\left[\begin{array}{cccc}
w_{11}{ }^{*} & w_{12}{ }^{*} & \cdots & w_{1 p}{ }^{*} \\
w_{21}{ }^{*} & w_{22}{ }^{*} & \ldots & w_{2 p}{ }^{*} \\
\vdots & \vdots & w_{i j}{ }^{*} & \vdots \\
w_{p 1}{ }^{*} & w_{2 p}{ }^{2} & \cdots & w_{p p}{ }^{*}
\end{array}\right]
$$

$$
\begin{aligned}
& \text { dengan } \\
& \qquad w_{i j}{ }^{*}=\frac{w_{i j}}{\sum_{j=1}^{p} w_{i j}}
\end{aligned}
$$

8. Menentukan defuzzifikasi nilai peramalan. Untuk menghasilkan nilai peramalan, matriks pembobot terstandarisasi $\left(\mathrm{W}^{*}\right)$ dikalikan dengan $m_{i}$. Adapun persamaan untuk menghitung peramalan adalah sebagai berikut:

$$
F_{i}=w_{i 1}^{*}\left(m_{i}\right)+w_{i 2}^{*}+\cdots+w_{i p}^{*}\left(m_{p}\right)
$$

\section{Metode Penelitian}

Data yang digunakan dalam penelitian ini adalah data sekunder yang diperoleh dari buku induk siswa tiap tahunnya. Data siswa baru yang digunakan mulai tahun ajaran 1998/1999 sampai tahun 2016/2017 yang kemudian dilakukan peramalan menggunakan program SPSS 16 dan Ms. Excel 2010. Program SPSS digunakan untuk mengetahui pola pergerakan data sedangkan Ms. Excel 2010 digunakan pada proses penentuan interval, menentukan himpunan Fuzzy Logical, 
proses defuzzifikasi nilai peramalan serta melakukan peramalan. Adapun tahapan dari penelitian ini adalah sebagai berikut:

1. Persiapan

Pada tahap ini dilakukan pengumpulan informasi terkait profil serta gambaran jumlah siswa baru yang mendaftar di Madrasa Aliyah (MA) Manhalul Ma'arif Darek tiap tahunnya.

2. Studi Literatur

Pada tahap ini dilakukan pengumpulan sumbersumber pustaka yang memberikan informasi mengenai penelitian dan sesuai dengan permasalahan yang ada.

3. Menentukan Motode

Pada tahap ini ditentukan motode apa yang sesuai dengan informasi yang diberikan pihak sekolah untuk melakukan peramalan jumlah siswa baru di Madrasah Aliyah (MA) Manhalul Ma'arif Darek.

4. Mengumpulkan Data

Pada tahap ini dilakukan pengumpulan data yaitu jumlah siswa baru di Madrasah Aliyah (MA) Manhalul Ma'arif Darek setiap tahun yang diperoleh dari database sekolah.

5. Analisis Data

Pada tahap ini dilakukan analisis data menggunakan metode yang sesuai dengan karakteristik data yang diperoleh untuk proses peramalan. Adapun metode peramalan yang digunakan dalam penelitian ini menggunakan metode Fuzzy Time Series Cheng dengan tahapan:
a. Penentuan Himpunan Semesta
b. Penentuan Interval
c. Menentukan Himpunan Fuzzy Logical
d. Fuzzy Logical Relationship dan Fuzzy Logical Relationship Group
e. Defuzzifikasi Nilai Peramalan
f. Melakukan Peramalan

6. Penarikan kesimpulan

Pada tahap ini dilakukan penarikan kesimpulan berdasarkan hasil peramalan yang diperoleh menggunakan metode Fuzzy Time Series Cheng.

\section{Hasil dan Pembahasan}

\subsection{Deskripsi Data}

Data yang digunakan dalam penelitian ini adalah data jumlah siswa pada Madrasah Aliyah (MA) Manhalul Ma'arif Darek. Data ini merupakan data time series yang diperoleh dari buku induk siswa tahunan Madrasah Aliyah (MA) Manhalul Ma'arif Darek mulai tahun 1988/1989 sampai tahun 2016/2017. Data tersebut kemudian diurutkan untuk mencari data minimum dan maksimum sehingga dapat ditentukan himpunan semestanya.

\subsection{Penentuan Himpunan Semesta}

Penentuan himpunan semesta menggunakan persamaan (2.8) sehingga diperoleh himpunan semesta dari jumlah siswa baru yang mendaftar pada tahun ajaran 1988/1989 sampai 2016 /2017 adalah:

$$
U=[141,14]
$$

\subsection{Penentuan Interval}

Adapun panjang interval ditentukan menggunakan langkah-langkah pada distribusi frekuensi yaitu sebagai berikut:

a. Menghitung Range (R)

Berdasarkan persamaan (2.9), diperoleh hasil sebagai berikut:

$$
R=(141-14)=127
$$

b. Menghitung Interval Kelas $(K)$

Penentuan interval kelas menggunakan aturan Sturges pada persamaan (2.10) sehingga diperoleh:

$$
\begin{aligned}
K & =1+3,322(\log n) \\
& =1+3,222(\log 29) \\
& =5,858086=6
\end{aligned}
$$

c. Menghitung Lebar Interval $l$

Lebar interval diperoleh dengan cara:

$$
l=\frac{R}{K}=\frac{127}{6}=21,167
$$

Berdasarkan nilai interval kelas $(K)$ maka diperoleh 6 interval dalam semesta pembicaraan yaitu $u_{1}, u_{2}, u_{3}, u_{4}, u_{5}, u_{6}$.

\subsection{Penentuan Himpunan Fuzzy Logical}

Penentuan himpunan fuzzy dari data jumlah siswa baru di Madrasah Aliyah (MA) Manhalul Ma'arif Darek dapat dilihat pada table 4.1 berikut.

\begin{tabular}{cccccc}
\multicolumn{6}{c}{ Tabel 4.1 Frekuensi Kepadatan Siswa Baru } \\
\hline $\begin{array}{l}\boldsymbol{U}_{\boldsymbol{i}} \\
\text { Batas } \\
\text { Bawah }\end{array}$ & $\begin{array}{l}\text { Batas } \\
\text { Atas }\end{array}$ & $\begin{array}{l}\text { Juml } \\
\text { ah } \\
\text { Data }\end{array}$ & $\begin{array}{l}\text { Jumlah } \\
\text { Sub } \\
\text { interval }\end{array}$ & $\begin{array}{l}\text { Lebar } \\
\text { Sub } \\
\text { interval }\end{array}$ \\
\hline 1 & 14 & 35,17 & 10 & 4 & 5,292 \\
2 & 35,167 & 56,33 & 12 & 5 & 4,233 \\
3 & 56,333 & 77,50 & 4 & 3 & 7,056 \\
4 & 77,500 & 98,67 & 0 & 1 & 21,167 \\
5 & 98,667 & 119,8 & 1 & 1 & 21,167 \\
6 & 119,83 & 141,0 & 2 & 2 & 10,583 \\
\hline
\end{tabular}

Penentuan lebar sub interval diperoleh dengan menggunakan persamaan berikut:

Lebar sub interval $(i)=$

batas atas (i)-batas bawah (i)

jumlah sub interval (i) 
Berdasarkan perhitungan dari tabel 4.1 maka diperoleh 11 sub interval yang menjadi domain dari himpunan interval fuzzy yang terbentuk seperti yang disajikan pada tabel 4.2 berikut.

Tabel 4.2 Interval Fuzzy Menggunakan Distribusi Frekuensi

\begin{tabular}{ccccc}
\hline $\boldsymbol{U}_{\boldsymbol{i}}$ & $\begin{array}{c}\text { Batas } \\
\text { Bawah }\end{array}$ & $\begin{array}{c}\text { Batas } \\
\text { Atas }\end{array}$ & $\begin{array}{c}\text { Jumlah } \\
\text { Sub } \\
\text { interval }\end{array}$ & $\begin{array}{c}\text { Nilai } \\
\text { Tengah } \\
\left(\boldsymbol{m}_{\boldsymbol{i}}\right)\end{array}$ \\
\hline$U_{1}$ & 14 & 19,292 & 5,292 & 16,646 \\
$U_{2}$ & 19,292 & 24,583 & 5,292 & 21,938 \\
$U_{3}$ & 24,583 & 29,875 & 5,292 & 27,229 \\
$U_{4}$ & 29,875 & 35,167 & 5,292 & 32,521 \\
$U_{5}$ & 35,167 & 39,400 & 4,233 & 37,283 \\
$U_{6}$ & 39,400 & 43,633 & 4,233 & 41,517 \\
$U_{7}$ & 43,633 & 47,867 & 4,233 & 45,750 \\
$U_{8}$ & 47,867 & 52,100 & 4,233 & 49,983 \\
$U_{9}$ & 52,100 & 56,333 & 4,233 & 54,217 \\
$U_{10}$ & 56,333 & 63,389 & 7,056 & 59,861 \\
$U_{11}$ & 63,389 & 70,444 & 7,056 & 66,917 \\
$U_{12}$ & 70,444 & 77,500 & 7,056 & 73,972 \\
$U_{13}$ & 77,500 & 98,667 & 21,167 & 88,083 \\
$U_{14}$ & 98,667 & 119,833 & 21,167 & 109,250 \\
$U_{15}$ & 119,833 & 130,417 & 10,583 & 125,125 \\
$U_{16}$ & 130,417 & 141,000 & 10,583 & 135,708 \\
\hline
\end{tabular}

Dari perhitungan interval himpunan fuzzy menggunakan distribusi frekuensi diperoleh 16 interval yang terbentuk sehingga diperoleh kumpulan fuzzy nilai-nilai linguistik menggunakan persamaan (2.13). Adapun nilai linguistik dari himpunan fuzzy diberikan pada tabel 4.3 berikut.

Tabel 4.3 Nilai Linguistik dari himpunan Fuzzy

\begin{tabular}{cl}
\hline Fuzzifikasi & \multicolumn{1}{c}{ Nilai Linguistik } \\
\hline A1 & Sangat turun drastis \\
A2 & Turun drastis \\
A3 & Sangat turun sekali \\
A4 & Turun sekali \\
A5 & Cukup turun \\
A6 & Turun \\
A7 & Sedikit turun \\
A8 & Normal \\
A9 & Sedikit naik \\
A10 & Naik \\
A11 & Cukup naik \\
A12 & Naik sekali \\
A13 & Sangat naik sekali \\
A14 & Naik drastis \\
A15 & Sangat naik drastis \\
A16 & Sangat sangat naik drastis \\
\hline
\end{tabular}

Berikutnya ditentukan Fuzzifikasi dan FLR yang merupakan hubungan antara setiap urutan data terhadap data berikutnya dalam bentuk himpunan fuzzy dapat dilihat pada tabel 4.4 sebagai berikut.

Tabel 4.4 Fuzzifikasi dan Fuzzy Logical Relationship (FLR)

\begin{tabular}{|c|c|c|c|}
\hline $\begin{array}{l}\text { Tahun } \\
\text { Ajaran }\end{array}$ & $\begin{array}{c}\text { Banyak } \\
\text { Siswa }\end{array}$ & Fuzzifikasi & FLR \\
\hline $1988 / 1989$ & 14 & A1 & - \\
\hline $1989 / 1990$ & 22 & $\mathrm{~A} 2$ & $\mathrm{~A} 1 \rightarrow \mathrm{A} 2$ \\
\hline 1990/1991 & 15 & A1 & $\mathrm{A} 2 \rightarrow \mathrm{A} 1$ \\
\hline 1991/1992 & 15 & A1 & $\mathrm{A} 1 \rightarrow \mathrm{A} 1$ \\
\hline $1992 / 1993$ & 25 & A3 & $\mathrm{A} 1 \rightarrow \mathrm{A} 3$ \\
\hline $1993 / 1994$ & 24 & A2 & $\mathrm{A} 3 \rightarrow \mathrm{A} 2$ \\
\hline $1994 / 1995$ & 26 & A3 & $\mathrm{A} 2 \rightarrow \mathrm{A} 3$ \\
\hline $1995 / 1996$ & 24 & A2 & $\mathrm{A} 3 \rightarrow \mathrm{A} 2$ \\
\hline $1996 / 1997$ & 48 & A8 & $\mathrm{A} 2 \rightarrow \mathrm{A} 8$ \\
\hline $1997 / 1998$ & 34 & A4 & $\mathrm{A} 8 \rightarrow \mathrm{A} 4$ \\
\hline $1998 / 1999$ & 36 & A5 & $\mathrm{A} 4 \rightarrow \mathrm{A} 5$ \\
\hline $1999 / 2000$ & 38 & A5 & $\mathrm{A} 5 \rightarrow \mathrm{A} 5$ \\
\hline $2000 / 2001$ & 46 & A7 & $\mathrm{A} 5 \rightarrow \mathrm{A} 7$ \\
\hline $2001 / 2002$ & 52 & A8 & $\mathrm{A} 7 \rightarrow \mathrm{A} 8$ \\
\hline $2002 / 2003$ & 72 & A12 & $\mathrm{A} 8 \rightarrow \mathrm{A} 12$ \\
\hline $2003 / 2004$ & 53 & A9 & $\mathrm{A} 12 \rightarrow \mathrm{A} 9$ \\
\hline $2004 / 2005$ & 65 & A11 & $\mathrm{A} 9 \rightarrow \mathrm{A} 11$ \\
\hline $2005 / 2006$ & 99 & A14 & $\mathrm{A} 11 \rightarrow \mathrm{A} 14$ \\
\hline $2006 / 2007$ & 121 & A15 & $\mathrm{A} 14 \rightarrow \mathrm{A} 15$ \\
\hline $2007 / 2008$ & 141 & A16 & $\mathrm{A} 15 \rightarrow \mathrm{A} 16$ \\
\hline $2008 / 2009$ & 70 & A11 & $\mathrm{A} 16 \rightarrow \mathrm{A} 11$ \\
\hline $2009 / 2010$ & 55 & A9 & $\mathrm{A} 11 \rightarrow \mathrm{A} 9$ \\
\hline $2010 / 2011$ & 42 & A6 & $\mathrm{A} 9 \rightarrow \mathrm{A} 6$ \\
\hline $2011 / 2012$ & 77 & A12 & $\mathrm{A} 6 \rightarrow \mathrm{A} 12$ \\
\hline $2012 / 2013$ & 34 & A4 & $\mathrm{A} 12 \rightarrow \mathrm{A} 4$ \\
\hline $2013 / 2014$ & 36 & A5 & $\mathrm{A} 4 \rightarrow \mathrm{A} 5$ \\
\hline $2014 / 2015$ & 39 & A5 & $\mathrm{A} 5 \rightarrow \mathrm{A} 5$ \\
\hline $2015 / 2016$ & 39 & A5 & $\mathrm{A} 5 \rightarrow \mathrm{A} 5$ \\
\hline $2016 / 2017$ & 43 & A6 & $\mathrm{A} 5 \rightarrow \mathrm{A} 6$ \\
\hline
\end{tabular}

Langkah selanjutnya adalah menentukan bobot relasi Fuzzy Logical Relationship menjadi Fuzzy Logical

Relationship Group (FLRG). Adapun FLRG yang dibentuk dari FLR dapat dilihat pada tabel 4.5 berikut.

Tabel 4.5 Fuzzy Logic Relation Group (FLRG)

\begin{tabular}{ccc}
\multicolumn{2}{c}{$\begin{array}{c}\text { Current State } \\
\left(\boldsymbol{A}_{\boldsymbol{i}}\right)\end{array}$} & Next State $\left(\boldsymbol{A}_{\boldsymbol{j}}\right)$ \\
\hline $\mathrm{A} 1$ & $\rightarrow$ & $\mathrm{A} 1, \mathrm{~A} 2, \mathrm{~A} 3$ \\
$\mathrm{~A} 2$ & $\rightarrow$ & $\mathrm{A} 1, \mathrm{~A} 3, \mathrm{~A} 8$ \\
$\mathrm{~A} 3$ & $\rightarrow$ & $\mathrm{A} 2$ \\
$\mathrm{~A} 4$ & $\rightarrow$ & $\mathrm{A} 5$ \\
$\mathrm{~A} 5$ & $\rightarrow$ & $\mathrm{A} 5, \mathrm{~A} 6, \mathrm{~A} 7$ \\
A6 & $\rightarrow$ & $\mathrm{A} 12$ \\
A7 & $\rightarrow$ & A8 \\
A8 & $\rightarrow$ & A4, A12 \\
\hline
\end{tabular}




\begin{tabular}{ccc}
\hline \multicolumn{2}{c}{$\begin{array}{c}\text { Current State } \\
\left(\boldsymbol{A}_{\boldsymbol{i}}\right)\end{array}$} & Next State $\left(\boldsymbol{A}_{\boldsymbol{j}}\right)$ \\
\hline A9 & $\rightarrow$ & A6, A11 \\
A10 & $\rightarrow$ & $\varnothing$ \\
A11 & $\rightarrow$ & A9, A14 \\
A12 & $\rightarrow$ & A4, A9 \\
A13 & $\rightarrow$ & $\varnothing$ \\
A14 & $\rightarrow$ & A15 \\
A15 & $\rightarrow$ & A16 \\
A16 & $\rightarrow$ & A11 \\
\hline
\end{tabular}

FLRG yang sudah dikelompokkan pada tabel 4.5 selanjutnya digunakan untuk memberikan bobot berdasarkan urutan dan perulangan yang sama. Berdasarkan persamaan (2.15) maka diperoleh bobot FLRG sebagai berikut:

$$
W=\left[\begin{array}{ccccccccccc}
1 & 1 & 1 & 0 & 0 & 0 & 0 & 0 & 0 & \cdots & 0 \\
1 & 0 & 1 & 0 & 0 & 0 & 0 & 1 & 0 & \cdots & 0 \\
0 & 2 & 0 & 0 & 0 & 0 & 0 & 0 & 0 & \cdots & 0 \\
0 & 0 & 0 & 0 & 2 & 0 & 0 & 0 & 0 & \cdots & 0 \\
0 & 0 & 0 & 0 & 3 & 1 & 1 & 0 & 0 & \cdots & 0 \\
0 & 0 & 0 & 0 & 0 & 0 & 0 & 0 & 0 & \cdots & 0 \\
0 & 0 & 0 & 0 & 0 & 0 & 0 & 1 & 0 & \cdots & 0 \\
0 & 0 & 0 & 1 & 0 & 0 & 0 & 0 & 0 & \cdots & 0 \\
0 & 0 & 0 & 0 & 0 & 1 & 0 & 0 & 0 & \cdots & 0 \\
\vdots & \vdots & \vdots & \vdots & \vdots & \vdots & \vdots & \vdots & \vdots & \cdots & 0 \\
0 & 0 & 0 & 0 & 0 & 0 & 0 & 0 & 0 & \cdots & 0
\end{array}\right]
$$

Setelah matriks bobot diperoleh, maka dilakukan standarisasi matriks pembobot. Adapun matriks pembobot yang telah distandarisasi adalah sebagai berikut:

\begin{tabular}{|c|c|c|c|}
\hline \multicolumn{2}{|c|}{$\begin{array}{c}\text { Current State } \\
\left(\boldsymbol{A}_{\boldsymbol{i}}\right)\end{array}$} & \multirow{2}{*}{$\begin{array}{c}\text { Next State } \\
\left(\boldsymbol{A}_{\boldsymbol{i}}\right) \\
\mathrm{A} 1, \mathrm{~A} 2, \mathrm{~A} 3\end{array}$} & \multirow{2}{*}{$\begin{array}{c}\text { Peramalan } \\
21,938\end{array}$} \\
\hline A1 & $\rightarrow$ & & \\
\hline A2 & $\rightarrow$ & $\mathrm{A} 1, \mathrm{~A} 3, \mathrm{~A} 8$ & 31,286 \\
\hline A3 & $\rightarrow$ & A2 & 21,938 \\
\hline A4 & $\rightarrow$ & A5 & 37,283 \\
\hline A5 & $\rightarrow$ & $\mathrm{A} 5, \mathrm{~A} 6, \mathrm{~A} 7$ & 39,823 \\
\hline A6 & $\rightarrow$ & A12 & 73,972 \\
\hline A7 & $\rightarrow$ & A8 & 49,983 \\
\hline A8 & $\rightarrow$ & $\mathrm{A} 4, \mathrm{~A} 12$ & 53,247 \\
\hline A9 & $\rightarrow$ & A6, A11 & 54,217 \\
\hline A10 & $\rightarrow$ & $\varnothing$ & 59,861 \\
\hline A11 & $\rightarrow$ & A9, A14 & 81,734 \\
\hline A12 & $\rightarrow$ & A4, A9 & 43,369 \\
\hline A13 & $\rightarrow$ & $\varnothing$ & 88,083 \\
\hline A14 & $\rightarrow$ & A15 & 125,125 \\
\hline A15 & $\rightarrow$ & A16 & 135,708 \\
\hline A16 & $\rightarrow$ & A11 & 66,917 \\
\hline
\end{tabular}

\subsection{Hasil Peramalan}

Berdasarkan tabel 4.7 diperoleh hasil peramalan dimana hasil tersebut dapat digunakan untuk meramalkan data pada periode waktu selanjutnya. Adapun hasil peramalan adalah sebagai berikut:

Tabel 4.8 Peramalan Jumlah Siswa Baru

Tabel 4.6 Matriks Pembobot Terstandarisasi

\begin{tabular}{ccccccccccc}
\hline$X_{(t-}$ & \multicolumn{110}{c}{$X_{(t)}$} \\
\cline { 2 - 13 } & A1 & A2 & A3 & A4 & A5 & A6 & A7 & A8 & A9 & A10 \\
A1 & $1 / 3$ & $1 / 3$ & $1 / 3$ & 0 & 0 & 0 & 0 & 0 & 0 & 0 \\
A2 & $1 / 3$ & 0 & $1 / 3$ & 0 & 0 & 0 & 0 & $1 / 3$ & 0 & 0 \\
A3 & 0 & 1 & 0 & 0 & 0 & 0 & 0 & 0 & 0 & 0 \\
A4 & 0 & 0 & 0 & 0 & 1 & 0 & 0 & 0 & 0 & 0 \\
A5 & 0 & 0 & 0 & 0 & $3 / 5$ & $1 / 5$ & $1 / 5$ & 0 & 0 & 0 \\
A6 & 0 & 0 & 0 & 0 & 0 & 0 & 0 & 0 & 0 & 0 \\
A7 & 0 & 0 & 0 & 0 & 0 & 0 & 0 & 1 & 0 & 0 \\
A8 & 0 & 0 & 0 & $1 / 2$ & 0 & 0 & 0 & 0 & 0 & 0 \\
A9 & 0 & 0 & 0 & 0 & 0 & $1 / 2$ & 0 & 0 & 0 & 0 \\
$\vdots$ & $\vdots$ & $\vdots$ & $\vdots$ & $\vdots$ & $\vdots$ & $\vdots$ & $\vdots$ & $\vdots$ & $\vdots$ & $\vdots$ \\
A1 & 0 & 0 & 0 & 0 & 0 & 0 & 0 & 0 & 0 & 0 \\
6 & & & & & & & & & & \\
\hline
\end{tabular}

\subsection{Proses Defuzzifikasi Nilai Peramalan}

Bobot untuk Fuzzy Logic Relation Group (FLRG) dan Defuzzifikasi dapat dilihat pada tabel 4.7 berikut.
Tabel 4.8 Peramalan Jumlah Siswa Baru

\begin{tabular}{|c|c|c|c|c|c|c|}
\hline & Tahun & $\begin{array}{l}\text { Banyak } \\
\text { Siswa }\end{array}$ & $\begin{array}{l}\text { Peramal } \\
\text { an }\left(F_{t}\right)\end{array}$ & $\mathrm{Xt}-\mathrm{Ft}$ & $\begin{array}{l}(\mathrm{Xt}-\mathrm{Ft}) \\
/ \mathrm{Ft}\end{array}$ & $(\mathrm{Xt}-\mathrm{Ft})^{2}$ \\
\hline & 1988 & 14 & & - & - & - \\
\hline & 1989 & 22 & 21.938 & 0.062 & 0.003 & 0.004 \\
\hline 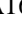 & 1990 & 15 & 31.286 & -16.286 & 1.086 & 265.234 \\
\hline & 1991 & 15 & 21.938 & -6.938 & 0.463 & 48.131 \\
\hline & 1992 & 25 & 21.938 & 3.062 & 0.122 & 9.378 \\
\hline & 1993 & 24 & 21.938 & 2.062 & 0.086 & 4.252 \\
\hline & 1994 & 26 & 31.286 & -5.286 & 0.203 & 27.942 \\
\hline & 1995 & 24 & 21.938 & 2.062 & 0.086 & 4.252 \\
\hline & 1996 & 48 & 31.286 & 16.714 & 0.348 & 279.358 \\
\hline & 1997 & 34 & 53.247 & -19.247 & 0.566 & 370.428 \\
\hline & 1998 & 36 & 37.283 & -1.283 & 0.036 & 1.646 \\
\hline & 1999 & 38 & 39.823 & -1.823 & 0.048 & 3.324 \\
\hline & 2000 & 46 & 39.823 & 6.177 & 0.134 & 38.153 \\
\hline & 2001 & 52 & 49.983 & 2.017 & 0.039 & 4.068 \\
\hline & 2002 & 72 & 53.247 & 18.754 & 0.260 & 351.694 \\
\hline & 2003 & 53 & 43.369 & 9.631 & 0.182 & 92.756 \\
\hline & 2004 & 65 & 54.217 & 10.783 & 0.166 & 116.273 \\
\hline & 2005 & 99 & 81.734 & 17.267 & 0.174 & 298.132 \\
\hline & 2006 & 121 & 125.125 & -4.125 & 0.034 & 17.016 \\
\hline & 2007 & 141 & 135.708 & 5.292 & 0.038 & 28.005 \\
\hline & 2008 & 70 & 66.917 & 3.083 & 0.044 & 9.505 \\
\hline & 2009 & 55 & 81.734 & -26.734 & 0.486 & 714.680 \\
\hline & 2010 & 42 & 54.217 & -12.217 & 0.291 & 149.255 \\
\hline & 2011 & 77 & 73.972 & 3.028 & 0.039 & 9.169 \\
\hline
\end{tabular}




\begin{tabular}{cccccc}
\hline Tahun & $\begin{array}{c}\text { Banyak } \\
\text { Siswa }\end{array}$ & $\begin{array}{l}\text { Peramal } \\
\text { an }\left(F_{t}\right)\end{array}$ & Xt-Ft & $\begin{array}{l}(\mathrm{Xt}-\mathrm{Ft}) \\
\text { /Ft }\end{array}$ & $(\mathrm{Xt}-\mathrm{Ft})^{2}$ \\
\hline 2012 & 34 & 43.369 & -9.369 & 0.276 & 87.778 \\
2013 & 36 & 37.283 & -1.283 & 0.036 & 1.646 \\
2014 & 39 & 39.823 & -0.823 & 0.021 & 0.678 \\
2015 & 39 & 39.823 & -0.823 & 0.021 & 0.678 \\
\hline 2016 & 43 & 39.823 & 3.177 & 0.074 & 10.092 \\
2017 & - & 73.972 & - & - & - \\
2018 & & 43.369 & & & \\
2019 & & 49.983 & & & \\
2020 & & 53.247 & & & \\
2021 & & 54.217 & & & \\
\hline
\end{tabular}

Berdasarkan hasil peramalan yang dilakukan selama lima periode berikutnya pada tabel 4.8 maka dilakukan pengujian keakuratan peramalan. Adapun keakuratan peramalan dapat dilihat dari nilai MSE dan MAPE berikut ini.

Tabel 4.9 Nilai MSE dan MAPE dari Hasil Peramalan

\begin{tabular}{cc}
\hline MSE & MAPE \\
101.5009 & $18.49 \%$ \\
\hline
\end{tabular}

Berdasarkan nilai dari MSE dan MAPE dapat dilihat bahwa keakuratan peramalan jumlah siswa baru pada Madrasah Aliyah (MA) Manhalul Ma'arif Darek menggunakan metode Fuzzy time series Cheng masih cukup akurat. Hal ini dilihat dari nilai MSE yaitu 101.5009 dan MAPE yaitu $18.49 \%$ yang berada diantara $10 \%$ dan $20 \%$.

\section{Kesimpulan}

Berdasarkan hasil penelitian yang telah dilakukan maka dapat ditarik kesimpulan yaitu:

1. Peramalan jumlah siswa baru pada Madrasah Aliyah (MA) Manhalul Ma'arif Darek menggunakan metode Fuzzy time series Cheng memiliki MSE sebesar 101.5009 dan nilai MAPE yaitu sebesar $18.49 \%$ yang berada diantara $10 \%$ dan $20 \%$.

2. Metode Fuzzy time series Cheng memiliki performa yang baik untuk memprediksi jumlah siswa baru pada Madrasah Aliyah (MA) Manhalul Ma'arif Darek yang dapat dlihat dari nilai MSE dan MAPE.

\section{DAFTAR PUSTAKA}

Aswi \& Sukarna. (2006). Analisis Deret Waktu. Makassar: Andira Publisher.

Fahmi, T., Sudarno, \& Wulandari, Y. (2013). Perbandingan Metode Pemulusan
Eksponensial Tunggal dan Fuzzy Time Series untuk Memprediksi Indeks Harga Saham Gabungan. Jurnal Gaussian. Vol. 2. No. 2. pp. 137- 146.

Makridakis, S., Wheelwright, S.C., \& Mcgee, V.E. (1995). Metode dan Aplikasi Peramalan Edisi Kedua, Jakarta: Penerbit Erlangga.

Ola, P.K., \& Katiko. (2019). Peramalan Menggunakan Metode Fuzzy Time Series Cheng dan Double Exponential Smoothing (Study Kasus: Jumlah Wisatawan Mancanegara di Candi Brobudur). Jurnal Statistika Industri dan Komputasi. Vol. 4. No. 1. pp 69-79

Rahmawati, Cynthia, E. P., \& Susilowati, K. (2019). Metode Fuzzy Time Series Cheng dalam Memprediksi Jumlah Wisatawan di Provinsi Sumatra Barat. Journal of Education Informatic Technology and Science. Vol. 1. No. 1. pp. 11-23.

Sumartini, Hayati, M. N., \& Wahyuningsih, S, (2017). Peramalan Menggunakan Metode Fuzzy Time Series Cheng. Jurnal Eksponensial. Vol. 8. No. 1. pp. 51-56.

Tauryawati, Mey Lisa \& Irawan, M. Isa. (2014). Perbandingan Metode Fuzzy Time Series Cheng dan Box-Jenkins untuk memprediksi IHSG. Jurnal Sains dan Seni Pomits Vol. 3. No. 2.

Wei, W.W.S. (2006). Time Series Analysis, Univariate and Multivariate Methods, 2nd Edition, USA : Pearson Education, Inc. 